\title{
Boron doses applied to soil during coffee development
}

\author{
Felipe Santinato', Tiago de Oliveira Tavares', Renato de Mello Prado', Gustavo Caione', \\ Vantuir de Albuquerque Silva ${ }^{2}$, Roberto Santinato ${ }^{3}$
}

'Universidade Estadual Paulista, Jaboticabal, SP, Brazi

${ }^{2}$ Technical High School of Espirito Santo State, Espírito Santo do Pinhal, SP, Brasil

${ }^{3}$ Foundation Procafé, Campinas, SP, Brasil

Correnponding author, e-mail: fpsantinato@hotmail.com

\begin{abstract}
The range between boron deficiency and toxicity in the coffee crop is narrow and the crop toxicity tolerance depends on the soil type, initial soil content and plant age. The objective of this study was to evaluate different levels of boron in the coffee crop during development and grown in a red clayey Oxisol. Treatments consisted of boron applications (zero; 2.48; 4.96; 9.92; 19.8 and $39.68 \mathrm{~kg}$ $\mathrm{ha}^{-1}$ ) in the boric acid form and applied to soil surface in the area of the tree crown projection. The six treatments were outlined in a randomized block design with four replications and ten plants per plot. The cultivar used was Catuaí IAC 144 with sixteen months old, grown in an Oxisol in Campinas, SP, Brazil. Foliar boron content was analyzed as a function of time by regression analysis. The levels in fruit and yield were analyzed by regression according to boron doses. It can be concluded that higher boron doses in the plant can be observed when fruits are at the first development stage. High doses can reduce yield productivity, being each kilogram of applied boron responsible for a reduction of 0.33 coffee bags. ha $^{-1}$.
\end{abstract}

Keywords: coffee, micronutrient, toxicity

\section{Doses de boro via solo em cafeeiros em fase de formação}

\section{Resumo}

A faixa entre a deficiência e a toxidez de boro na cultura do café é estreita e a tolerância da cultura à toxicidade depende do tipo de solo, teor inicial no solo e da idade da planta. Objetivouse avaliar diferentes níveis de boro no cafeeiro em fase de formação, cultivado em um Latossolo Vermelho argiloso. Os tratamentos consistiram de doses de boro (zero; 2,48; 4,96; 9,92; 19,8 e 39,68 kg $\mathrm{ha}^{-1}$ ), na forma de ácido bórico, aplicado via solo superficialmente em faixa na projeção da copa do cafeeiro. Os seis tratamentos foram delineados em blocos ao acaso, com quatro repetições, em parcelas de dez plantas. A cultivar utilizada foi Catuaí Vermelho IAC 144 com dezesseis meses de idade, cultivado em Latossolo Vermelho distroférrico, em Campinas, SP, Brasil. Os teores foliares de boro foram analisados em função do tempo por meio de análise de regressão. Os teores nos frutos e a produtividade foram analisados por meio de regressão em função das doses de B. Conclui-se que os maiores teores de B na planta são atingidos no período que os frutos encontram-se na fase de chumbinho. Altas doses reduzem a produtividade, na qual, para cada quilograma de boro aplicado, tem-se a redução de 0,33 sacas de café ha-1.

Palavras-chave: café, micronutriente, toxicidade 


\section{Introduction}

The low crop yield across the world is mostly due to nutritional disorders, including it's the mineral toxicity or deficiency (Amaral et al., 2011). During years of potential higher yields for the coffee crop, micronutrient deficiency can be observed, such as boron (B) (Martinez et al., 2003), due to its lower availability in Brazilian soils under cultivation, especially in the Cerrado region (Fernandes et al., 2012a). Its main source is the organic matter (Carmo et al., 2012), and due to the small availability in Brazilian soils, the nutrient must be supplied to the crops (Fernandes et al., 2013). The proper correction of B-deficient soils with the use of fertilizers with boron depends on various factors, such as application form source and time (Rosolem et al., 2007), beyond the soil type (Fernandes et al. 2012 b). Nutritional balance is extremely important because some nutrient in excess can inhibited others (Prado, 2008).

The borated fertilization in coffee is widely used, but the use of higher doses can cause plant toxicity, because the range between appropriate and toxic levels is relatively narrow for most crops. The B mobility varies widely among plant species, which has implications in the expression of its eficiency or toxicity in different species and in the management of fertilization with this micronutrient (Viégas et al., 2004; Bastos \& Carvalho, 2004). Symptoms of B toxicity in coffee are characterized by the appearance of yellow-green spots on older leaves, where the micronutrient would stay (Brown \& Hu, 1998), evolving to the appearance of small dark spots, complete burning on the edges of the leaves and its fall (Malavolta, 2006).

Knowledge of appropriate $B$ dose to be provided for young coffee plants requires more attention, because the toxicity may be more severe in this period (Mattiello et al., 2009), since its sufficiency range is narrow (Gontijo et al., 2007). However, little is known about this micronutrient effects during the coffee formation stage. Therefore, this study aimed to evaluate the coffee crop tolerance in the formation phase to the application of high boron doses in a red clayey oxisol.

\section{Material and Methods}

The experiment was conducted in the city of Campinas, SP, Brazil, with geographic coordinates of $22^{\circ} 51^{\prime} 52,23^{\prime \prime}$ south latitude and $47^{\circ} 02^{\prime} 51,63^{\prime \prime}$ west longitude, altitude of $670 \mathrm{~m}$, in an Oxisol. The coffee areas was seeded with the 'Vermelho IAC 144', planted in January 2010, with sixteen months old. In the area were collected soil samples $(0-20 \mathrm{~cm})$ prior to the experiment and chemical analysis for fertility purposes were performed, according to the methodology proposed by Raij et al. (2001), with the following results: $\mathrm{pH}\left(\mathrm{CaCl}_{2}\right)=5,7 ; \mathrm{M} . \mathrm{O} .=34 \mathrm{~g} \mathrm{dm}^{-3} ; \mathrm{P}_{\text {-resina }}=$ $184 \mathrm{mg} \mathrm{dm}^{-3} ; \mathrm{K}^{+}=3,9 \mathrm{mmol}_{\mathrm{c}} \mathrm{dm}^{-3} ; \mathrm{Mg}^{+2}=6 \mathrm{mmol}_{\mathrm{c}}$ $\mathrm{dm}^{-3} ; \mathrm{Ca}^{+2}=35 \mathrm{mmol}_{\mathrm{c}} \mathrm{dm}^{-3} ; \mathrm{S}=16 \mathrm{mg} \mathrm{dm}^{-3} ; \mathrm{Na}=$ $0,4 \mathrm{mmol}_{\mathrm{c}} \mathrm{dm}^{-3} ;(\mathrm{H}+\mathrm{Al})=20 \mathrm{mmol}_{\mathrm{c}} \mathrm{dm}^{-3} ; \mathrm{CEC}=$ $65,3 \mathrm{mmol}_{\mathrm{c}} \mathrm{dm}^{-3} ; \mathrm{V}=69 \% ; \mathrm{B}=0,7 \mathrm{mg} \mathrm{dm}^{-3} ; \mathrm{Fe}=36$ $\mathrm{mg} \mathrm{dm}^{-3} ; \mathrm{Zn}=5,8 \mathrm{mg} \mathrm{dm}^{-3} ; \mathrm{Cu}=6,9 \mathrm{mg} \mathrm{dm}^{-3}$ and $\mathrm{Mn}=8 \mathrm{mg} \mathrm{dm}^{-3}$.

During the study period data of average air temperature and precipitation during the 2011 and 2012 crop years were collected (Figure 1). These results indicate that during the experimental period no environmental stress was observed and the temperature and precipitation were adequate for the normal plant development (Matiello et al., 2010).

The spacing between lines of the coffee was $4.0 \mathrm{~m}$ and $0.5 \mathrm{~m}$ between plants, which provides 5,000 plants $\mathrm{ha}^{-1}$. The treatments consisted of six boron doses: zero; $2.48 ; 4.96$; 9.92; 19.8 and $39.68 \mathrm{~kg} \mathrm{ha}^{-1}$ in the form of boric acid (17.0\% B). The micronutrient was applied to the soil with $0.1 \mathrm{~m}$ range in the plant crown projection area (Fernandes et al., 2012a). The experiment design was a complete randomized blocks with four repetitions. Each plot consisted of six plants, considering four as useful for evaluations. The experiment was established on May 14, 2011.

Cultural practices for to the management of fertilization, plant protection and weed control were made based on the current recommendations for the region, according to MAPA/PROCAFÉ (Matiello et al., 2010).

Evaluations of the coffee crop nutrition were performed from leaf samples at 30; 90; 180; 240; 300 and 390 days after the treatment application. These days corresponded to the months of May, June, August and November 
2011 and January, March and June 2012. In each evaluation 20 leaves were collected from the third and fourth pairs of the middle third of the plant branches, for each plot. The squaring of coffee lines in each plot was made to eliminate crop residues that could mix with the production. Then a collecting cloth was set on each side of the coffee line, avoiding losses by detachment.
At harvest, which began when fruit was $15 \%$ of green (Matiello et al., 2010), the fruits were divided according to the maturation stage the measurements were carried out with the use of graduated containers. After determining the volume, the values have been converted to the equivalent of processed coffee $\left(\mathrm{kg} \mathrm{ha}^{-1}\right)$.

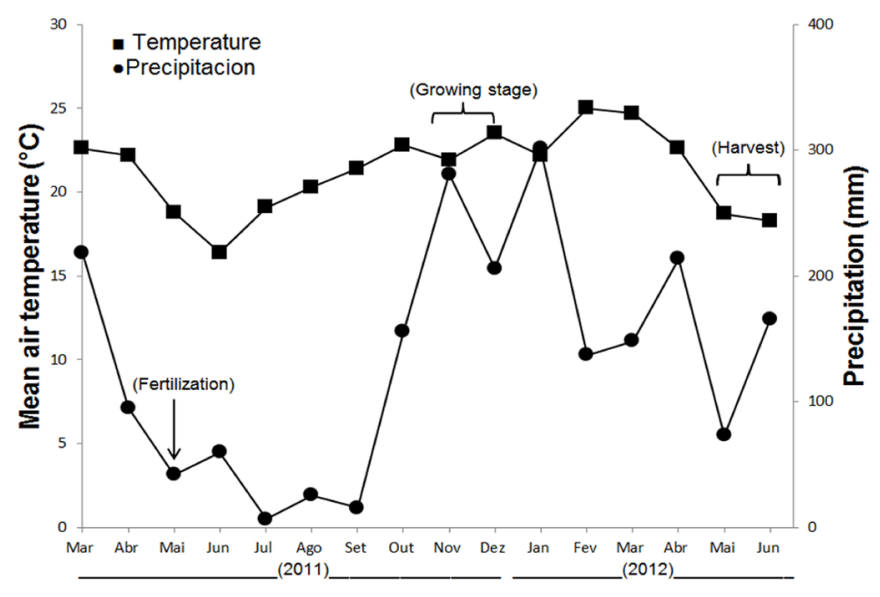

Figure 1. Average air temperature and rainfall during the experiment period,

The plant materials were weighed, ground in a stainless steel Wiley mill, passed trough a mesh sieve of $0.841 \mathrm{~mm}^{2}$ and packed in paper bags for the chemical analysis. The B content in plant tissue (leaf and fruit) was analyzed according to the methodology proposed by Bingham (1982).

These data were submitted to analysis of variance by $F$ test $(P<0.05)$ and regression analysis for significant effects using the SISVAR ${ }^{\circledR}$ statistic program (Ferreira, 2011). The coefficients of each model components were tested and the significant models with higher coefficient of determination were choosed.

\section{Results and Discussion}

The application of $B$ doses in the soil resulted in a linear increase in the $B$ foliar contents of coffee for all evaluated months, corresponding to winter, spring, summer and fall seasons (Figure 2). It was noted that the highest B content achieved the leaf sample that was taken 90 days after the nutrient application (Figure 2b).

There was an increase in foliar B content over the plant cycle after the application of this nutrient, reaching the maximum point of 104.39; 252.02; 207.18; 204.93; 132,28 and $140.04 \mathrm{mg} \mathrm{kg}^{-1}$ at $30,90,180,240,300$ and 390 days, respectively (Figure 2). The maximum leaf content of $B$, with the use of higher doses of the nutrient, was reached in a short time after the soil application when compared to lower doses of the nutrient. This was observed probably due to the increased area of element contact and the absorption of micronutrients provided by the higher doses applied.

The foliar B content, regardless the applied dose increased with a quadratic function of days and the maximum peak was obtained at 217 days after the nutrient application (Figure 2b), corresponding to the month of December, period of the grain formation. This result is explained by the physiological function of boron, that is required for fruit cell expansion (Prado, 2008; Tomaz et al., 2011). In September, the foliar B content increased (Figure 2b) during the period before coffee flowering, when the plant requires large amounts of this element. Other authors also founded similar results, and reported that the increased demand for B by the plant occurred during the reproductive phase (Blevins \& Lukaszewski, 1998). However, weather changes can influence plant metabolism, and consequently the absorption of nutrients (Huang 
et al., 2005).

Currently, the practice of using B before and after flowering in coffee is commonly used to obtain greater "fixation" during flowering, increasing its productivity (Fernandes et al., 2012b). Between January and March (240-300 days after application), it was observed that the
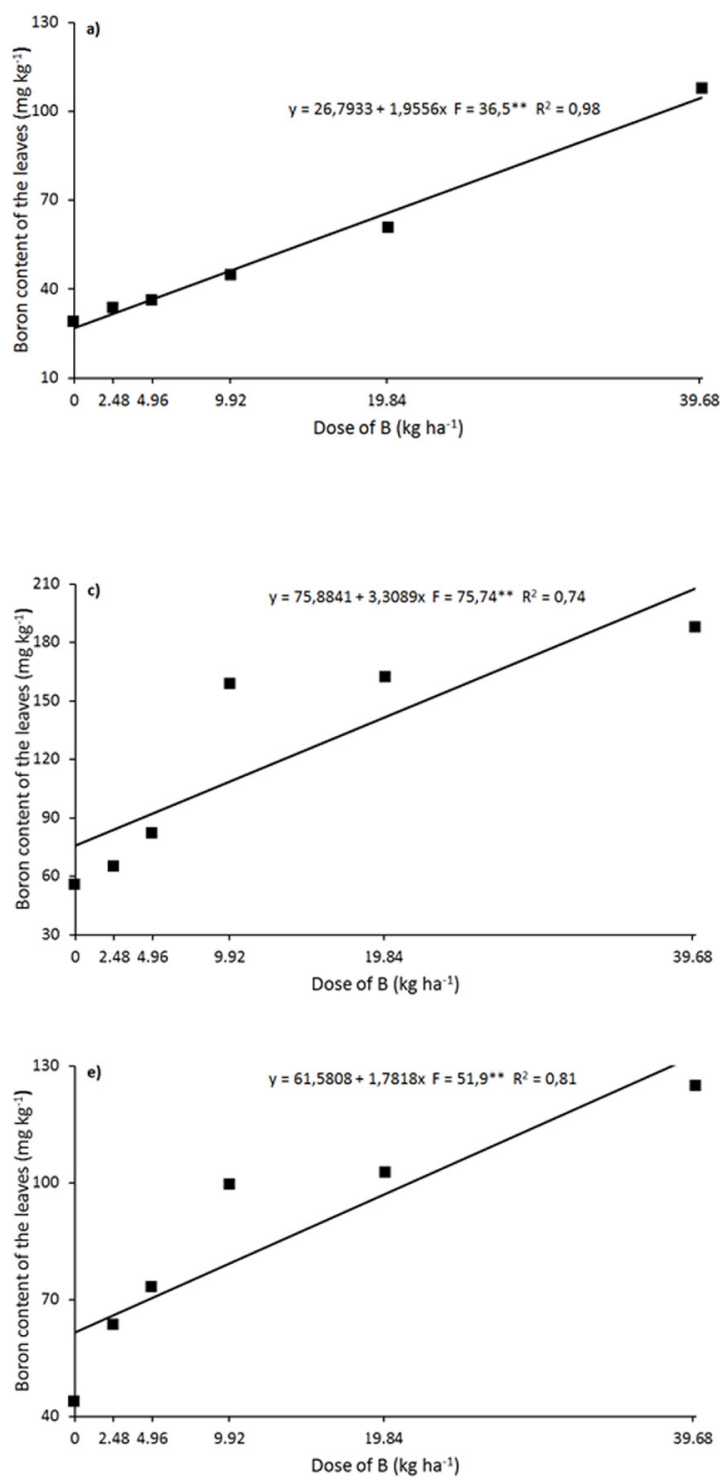

Figure 2. Foliar B in coffee at 30 (a), 90 (b), 180 (c), 240 (d), 300 (e) and 390 (f) days after the application of boron dose in the soil.

The optimum foliar B content for coffee, considering third and fourth pairs of leaves collected in the months corresponded to the summer period was between 60.0 and $80.0 \mathrm{mg}$ $\mathrm{kg}^{-1}$ (Malavolta, 2006). It was observed that the dose of 2.48 and $4.96 \mathrm{~kg} \mathrm{ha}^{-1}$ of boron increased the $B$ leaf contents, reaching values that are appropriate to the crop for culture during the first maturation stage, however, for increasing nutrient boron content in leaves decreased (Figure 3). This element was transported to fruit, that participates in cell division, differentiation and carbohydrate transport from leaves to fruit (Prado, 2008). For the higher dose, this decrease was not observed, probably due to the large nutrient amount added to the soil.
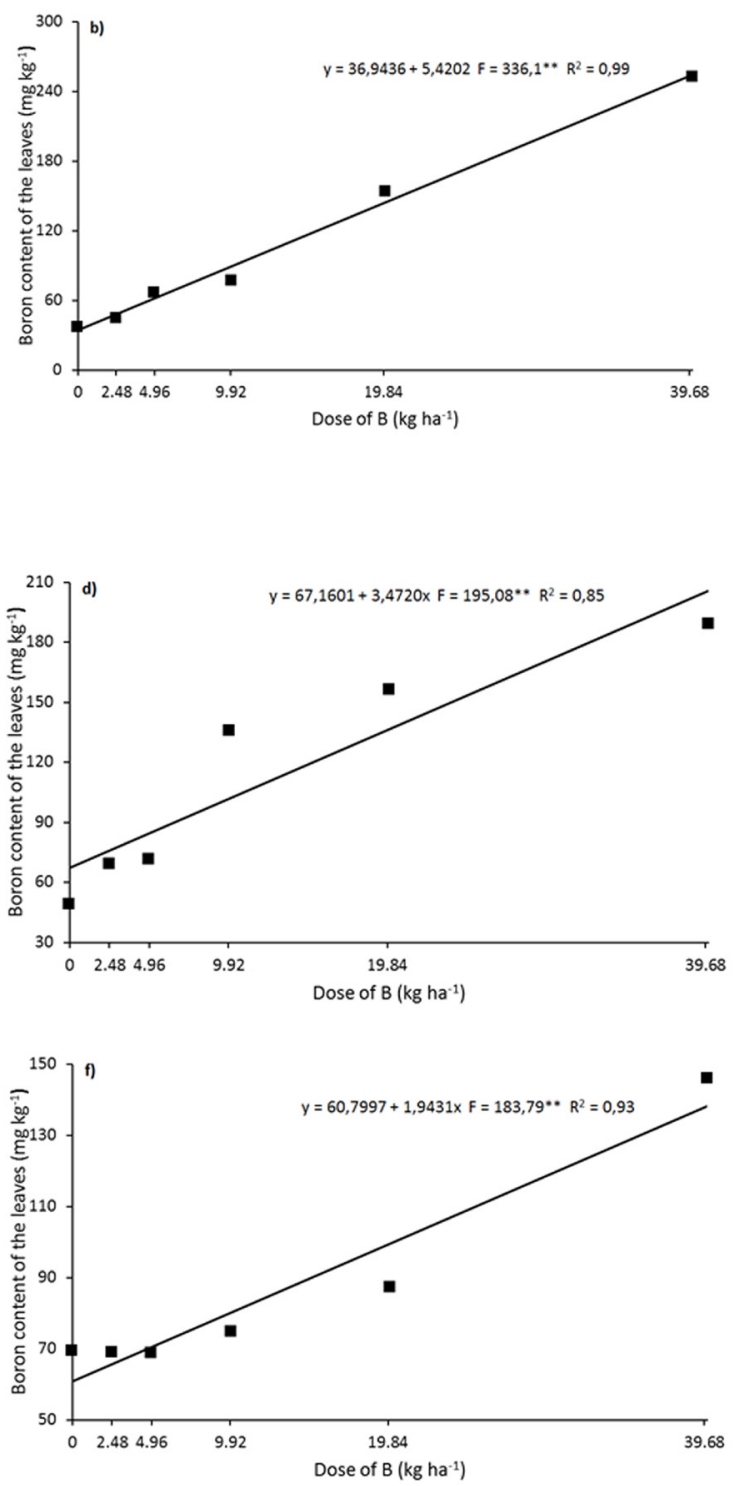

doses, the values reached were above the adequate values. After this phenological phase the contents decreased, but still had high values. The highest dose tested promoted very high boron contents, from the first evaluation, carried out 30 days after treatment, reaching the higher content 90 days after treatment with the higher dose, with contents above the toxicity level, which is $200.0 \mathrm{mg} \mathrm{kg}^{-1}$ (Malavolta , 2006). However, 
despite a B content of $252.02 \mathrm{mg} \mathrm{kg}^{-1}$, there was no evidence of visual symptoms of toxicity of this micronutrient in the studied plants. The pioneering experiment of Franco \& Gallo (1976) tested high $B$ doses in recently transplanted plants, grown in soils with clayey and sandy texture. The authors observed that the sandy soil required dose to induce toxicity symptoms was $11.05 \mathrm{~kg} \mathrm{ha}^{-1} \mathrm{~B}$, with leaf content around to $285.0 \mathrm{mg} \mathrm{kg}^{-1}$ of B. In clay soils, the applied dose for the appearance of toxicity symptoms was $48.62 \mathrm{~kg} \mathrm{ha}^{-1} \mathrm{~B}$, with the leaf content of $213.0 \mathrm{mg} \mathrm{kg}^{-1}$ of $\mathrm{B}$. This study shows that the doses that caused B toxicity to the coffee crop were different for cultivated soils, and the clayey is more tolerant to higher doses of this nutrient. In another study, Correa et al. (1985) evaluated the coffee seedlings response to boron application in two Oxisols (75 and $11 \%$ clay), reaching the conclusion that the adsorption capacity depends on soil texture, which means, higher the content of clay, higher the adsorption.

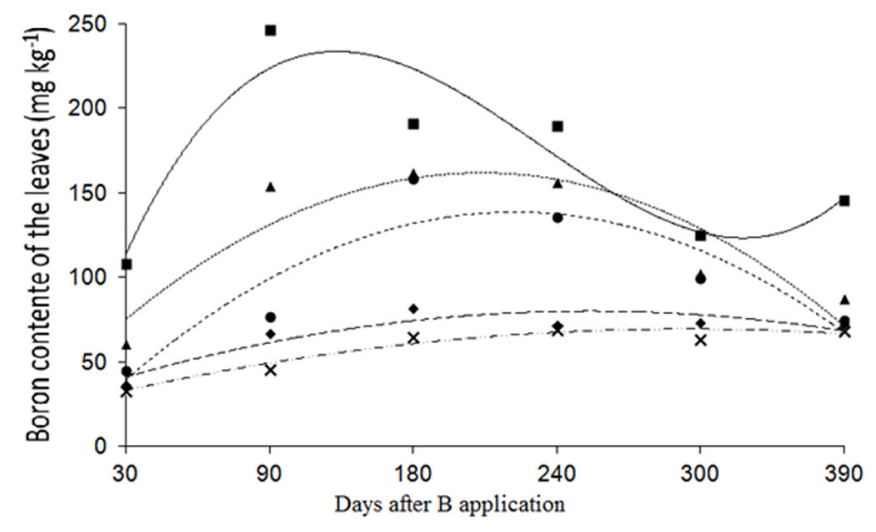

Subtitle:

xy $\left(2,48 \mathrm{~kg} \mathrm{ha}^{-1}\right.$ de $\left.B\right)=25,85+0,28 x-0,0004 x^{2} ; R^{2}=0,95 ; F=23,4^{* *}$

- $y\left(4,98 \mathrm{~kg} \mathrm{ha}^{-1}\right.$ de $\left.B\right)=32,41+0,36 x-0,0007 x^{2} ; R^{2}=0,80 ; F=64,9 * *$

-y $\left(9,98 \mathrm{~kg} \mathrm{ha}^{-1}\right.$ de $\left.B\right)=10,11+1,14 x-0,0025 x^{2} ; R^{2}=0,83 ; F=171,1^{* *}$

$\Delta y\left(19,95 \mathrm{~kg} \mathrm{ha}^{-1}\right.$ de $\left.\mathrm{B}\right)=52,87+1,02 x-0,0025 \mathrm{x}^{2} ; R^{2}=0,71 ; F=192,0^{* *}$

y $\left(39,90 \mathrm{~kg} \mathrm{ha}^{-1}\right.$ de $\left.B\right)=14,75+3,98 x-0,0211 x^{2}+0,00003 x^{3} ; R^{2}=0,85 ; F=216,6^{* *}$

Figure 3. Temporal variation of foliar boron according to the application of

different doses of the element in an oxisol cultivated with coffee Catuaí IAC 144.

The B levels in coffee fruits presented increasing linear values depending on this micronutrient dose (Figure 4), which was also observed for leaf content, indicating that the plant the nutrient accumulation mechanism is in the grain. According to Laviola et al. (2007) the accumulation of $B$ and $Z n$ in the fruits are larger than other micronutrients, as both have great importance in cell division processes and stabilization of membranes of newly formed cells.

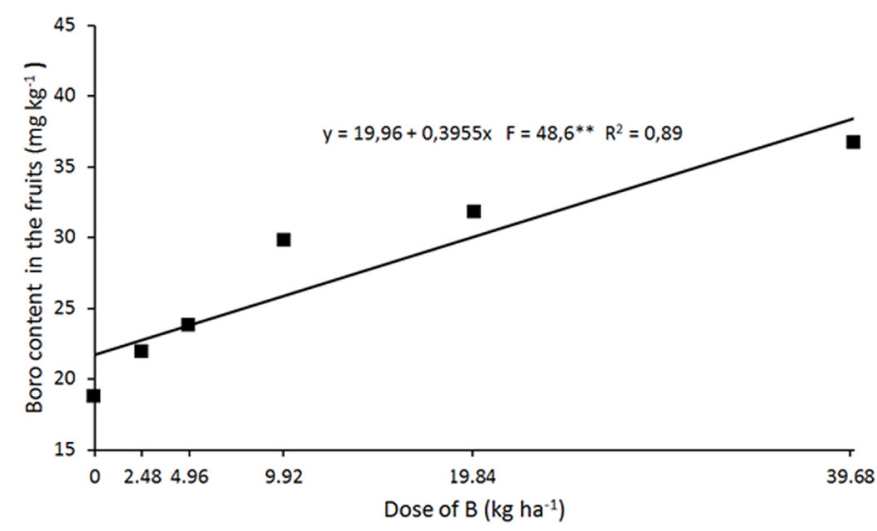

Figure 4. Contents of $B$ in the fruits according to the applied treatments. 
The increasen in boron doses resulted in decreased coffee yield, following a linear model (Figure 5), which is explained by high levels of boron in plant leaves (Figure 3). It was observed that the application of $B$ doses resulted in a decrease of 13.1 coffee bags ha-1 ${ }^{-1}$ corresponding to a reduction of $25.6 \%$ in the crop yield. Checking the slope of the line, for each kilogram of applied boron, a decrease of 0.33 coffee bags ha-1 was observed, demonstrating the detrimental effect on the plant. It was noted that the decrease of productivity due the B effect lead to nutrient disorders on subcellular or molecular level, however, no tissue damage was observed and this fact was not diagnosed as symptoms in plants. Harmful effects of the B excess in coffee yield were also reported by other authors (Furlani Junior et al., 2004).

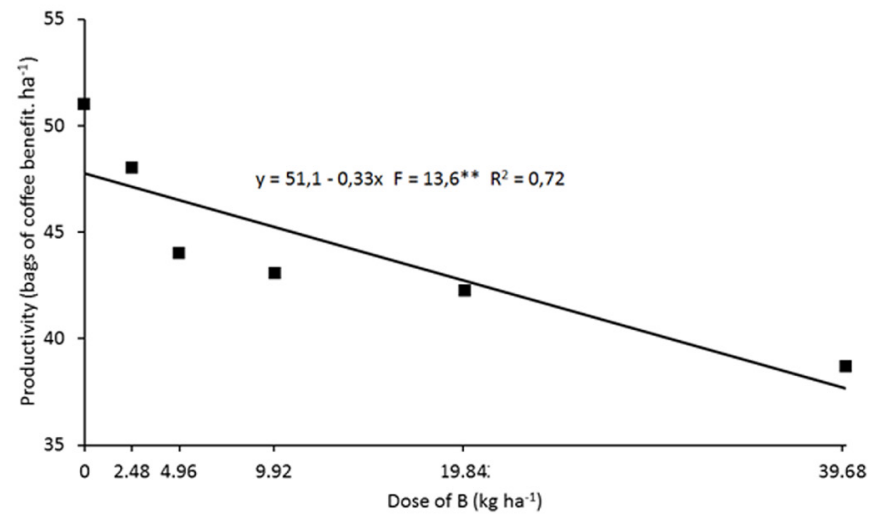

Figure 5. Catuaí IAC 144 coffee yield for the first harvest, according to B doses.

\section{Conclusions}

Higher levels of boron are achieved when fruits are in the first stage of maturity (December).

The reduction in yield due to boron toxicity occurs even when the visual symptoms can not be observed.

In clay soils, for each kilogram of boron added, the reduction of 0.33 coffee bags ha $^{-1}$ was observed.

\section{References}

Amaral, J.F.T., Martinez, H.E.P., Laviola, B.G., Tomaz, M.A., Fernandes Filho, E.I., Cruz, C.D. 2011. Produtividade e eficiência de uso de nutrientes por cultivares de cafeeiro. Coffee Science 6: 6574.

Bastos, A.R.R., Carvalho, J.G. 2004. Absorção radicular e redistribuição do boro pelas plantas, e seu papel na parede celular. Revista Universidade Rural, Série Ciência da Vida 24: 4766.

Bingham, F.T. 1982. Boron. In: Page, A.L. (ed.) Methods of soil analysis: Chemical and microbiological properties. American Society of Agronomy, Madison, United States. p. 431- 447.

Blevins, D.G., Lukaszewski, K.M. 1998. Boron in plant structure and function. Annual Review of Plant Physiology and Plant Molecular Biology49: 481-500.
Brown, P.H., Hu, H. 1998. Pholem boron mobility in diverse plant species. Botanica Acta, $111: 331$ 335.

Carmo, D.L. Nannetti, D.C., Lacerda, T.M., Nannetti, A.N., Santos, D.J.E. 2012. Micronutrientes em solo e folha de cafeeiro sob sistema agroflorestal no sul de Minas Gerais. Coffee Science 7: 76-83.

Correa, A.E., Pavan, M.A., Miyazawa, M. 1985. Aplicação de boro no solo e respostas do cafeeiro. Pesquisa Agropecuária Brasileira 20: 177-181.

Fernandes, A.L.T., Partelli, F.L., Bonomo, R., Golynski, A. 2012a. A moderna cafeicultura dos cerrados brasileiros. Pesquisa Agropecuária Tropical 42: 231-240.

Fernandes, A.L.T., Santinato, F., Ferreira, R.T., Santinato, R. 2013. Redução da adubação mineral do cafeeiro arábica coma utilização de palha de café. Coffee Science 8: 324-336.

Fernandes, A.L.T., Santinato, F., Santinato, R. 2012b. Fontes de boro na produção do cafeeiro em solo de cerrado. Enciclopédia Biosfera 8: 954960.

Ferreira, D.F. 2011. Sisvar: a computer statistical analysis system. Ciência e Agrotecnologia 35: 1039-1042.

Franco, C.M., Gallo, J.R. 1976. Toxidade de boro ao cafeeiro. Série Experimentação Cafeeira 1: 
$1-10$.

Furlani Júnior, E., Alves, C.C., Lazarini, E., Ferrari, S. 2004. Aplicação de calcário e boro em cafeeiro (Coffea arábica L.). Cultura Agronômica 13:1-25.

Gontijo, R.A.N., Carvalho, J.G., Guimarães, R.J., Mendes, A.N.G., Andrade, W.E.B. 2007. Faixas críticas de teores foliares de micronutrientes em mudas de cafeeiro (Coffea arábica L.). Coffee Science 2: 135-141.

Huang, L., Ye, Z., Bell, R. W., Dell, B. 2005. Boron nutrition and chilling tolerance of warm climate crop species. Annals of Botany 96: 755-767.

Laviola, B.G., Martinez, H.E.P., Salomão, L.C.C., Cruz, C.D., Mendonça, S.M., Rosado, L.D.S. 2007. Acúmulo de nutrientes em frutos de cafeeiro em duas altitudes de cultivo: micronutrientes. Revista Brasileira de Ciência do Solo 31: 1439-1449.

Malavolta, E. 2006. Manual de Nutrição de Plantas. Editora Agronômica Ceres Ltda, São Paulo, Brasil. 631 p.

Martinez, H.E.P., Menezes, J.F.S., Souza, R.B., Venegas, V.H.A., Guimarães, P.T.G. 2003. Faixas críticas de concentrações de nutrientes e avaliação do estado nutricional de cafeeiros em quatro regiões de Minas Gerais. Pesquisa Agropecuária Brasileira 38: 703-13.

Matiello, J.B., Santinato, R., Garcia, A.W.R., Almeida, S.R.A., Fernandes, D.R. 2010. Cultura do Café no Brasil, Manual de Recomendações. Fundação Procafé, Varginha. 542p.

Mattiello, E.M., Raiz, H.A., Silva, I.R., Barros, N.F., Neves, J.C.L., Behling, M. 2009. Transporte de boro no solo e sua absorção por eucalipto. Revista Brasileira de Ciência do Solo 33:1281-1290.

Prado, R.M. 2008. Nutrição de Plantas. Editora UNESP, São Paulo. 407p.

Raij, B.V., Andrade, J.C., Cantarella, H., Quaggio, J.A. (Ed.). 2001. Análise química para avaliação da fertilidade de solos tropicais. IAC, Campinas. $285 p$.

Rosolem, C.A., Leite, V.M. 2007. Coffee leaf and stem anatomy under boron deficiency. Revista Brasileira de Ciência do Solo 31: 477-483.

Tomaz, M.A., Martinez, H.E.P., Rodrigues, W.N., Ferrari, R.B., Pereira, A.A., Sakiyma, N.S. 2011. Eficiência de absorção e utilização de boro, zinco, cobre, manganês em mudas enxertadas de cafeeiro. Revista Ceres 58: 108-114.

Viégas, I.J.M., Thomaz, M.A.A., Silva, J. F. Conceição, H.E.O., Naiff, A.P.M. 2004. Efeito da omissão de macronutrientes e boro no crescimento, nos sintomas de deficiências nutricionais e na composição mineral de plantas de camucamuzeiro. Revista Brasileira de Fruticultura 26: 315-319. 